\title{
A Double Helix Relationship of Use and Redesign in IS
}

\author{
Professor Emeritus Hans-Erik Nissen, Lund University, Sweden \\ hans.nissen@telia.com
}

Peter Bednar, University of Portsmouth, UK and Lund University, Sweden

peter.bednar@ics.lu.se

\author{
Christine Welch, University of Portsmouth, UK \\ christine.welch@port.ac.uk
}

\begin{abstract}
In the past, Information Systems Research (ISR) mainly has focused on developing, designing, and implementing computerized parts of informing systems. Even studies from a "user" perspective relate to information and communication technology (ICT), often on an abstract level. Since the advent of the ICT industry there has been a tendency to describe professionals in their practice, or people in their daily lives as 'users' of ICT. It is not obvious why this label should be applied. The ICT industry offers products and services to professionals and to people in their daily lives. These products and services require critical assessment to see what helps whom in particular situations. There is also a need to appraise them with respect to unintended consequences.

Such critical assessment furnishes challenges to the ICT industry. More ISR seems to be needed with the intention of learning both from earlier ICT projects and from research carried out in other fields. This could comprise studying uses of earlier ICT artifacts and studies of how to redesign them to make people better informed and more knowledgeable. Becoming better informed and more knowledgeable calls for a lot of learning and unlearning. These processes always have to start from the situations in which the learners live. Designers of new ICT artifacts have not always been fully aware of this fundamental prerequisite for learning. We believe one way of supporting this kind of ISR is to reflect on the question: 'In which ways could studies of the use-side particularly benefit from a relationship to philosophical frameworks such as hermeneutics and phenomenology?'
\end{abstract}

The editors will introduce the mini-strand by presenting an overview of the contributions made to the special issue of Informing Science to which the strand relates. They will go on to contribute

Material published as part of this publication, either on-line or in print, is copyrighted by the Informing Science Institute. Permission to make digital or paper copy of part or all of these works for personal or classroom use is granted without fee provided that the copies are not made or distributed for profit or commercial advantage AND that copies 1) bear this notice in full and 2) give the full citation on the first page. It is permissible to abstract these works so long as credit is given. To copy in all other cases or to republish or to post on a server or to redistribute to lists requires specific permission and payment of a fee. Contact Publisher@InformingScience.org to request redistribution permission. some thoughts of their own relating to the theme.

Keywords: Information Systems Research, Systems Analysis, Hermeneutic Dialectics, Phenomenology, Critical Systems Thinking. 


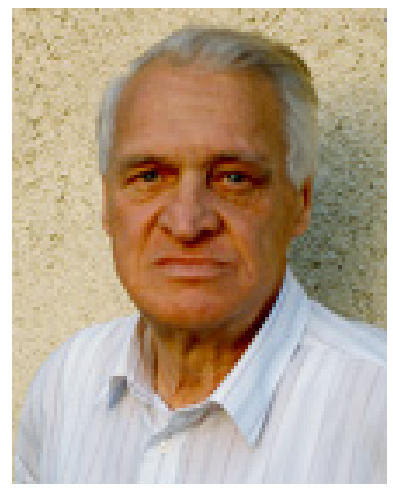

\section{Biographies}

Professor Emeritus Hans-Erik Nissen, since 1991 a senior research fellow at the department of Informatics at Lund University after years of demonstrated research excellence within the information systems field. He graduated in chemistry from the Royal Institute of Technology, Stockholm. He then for many years work in various positions in the Swedish Pulp, Paper and Timber industry before reentering academia.

Peter Bednar, Senior Lecturer at School of Computing, University of Portsmouth, UK is also affiliated with the department of Informatics at Lund University, Sweden. His research covers contextual analysis and information systems development, apart from working at different teaching and research institutions he has also several years of industrial experience.

Christine Welch, Senior Lecturer at Portsmouth Business School, University of Portsmouth. Her research activity is related to systems thinking and systems analysis. She is an experienced academic. 